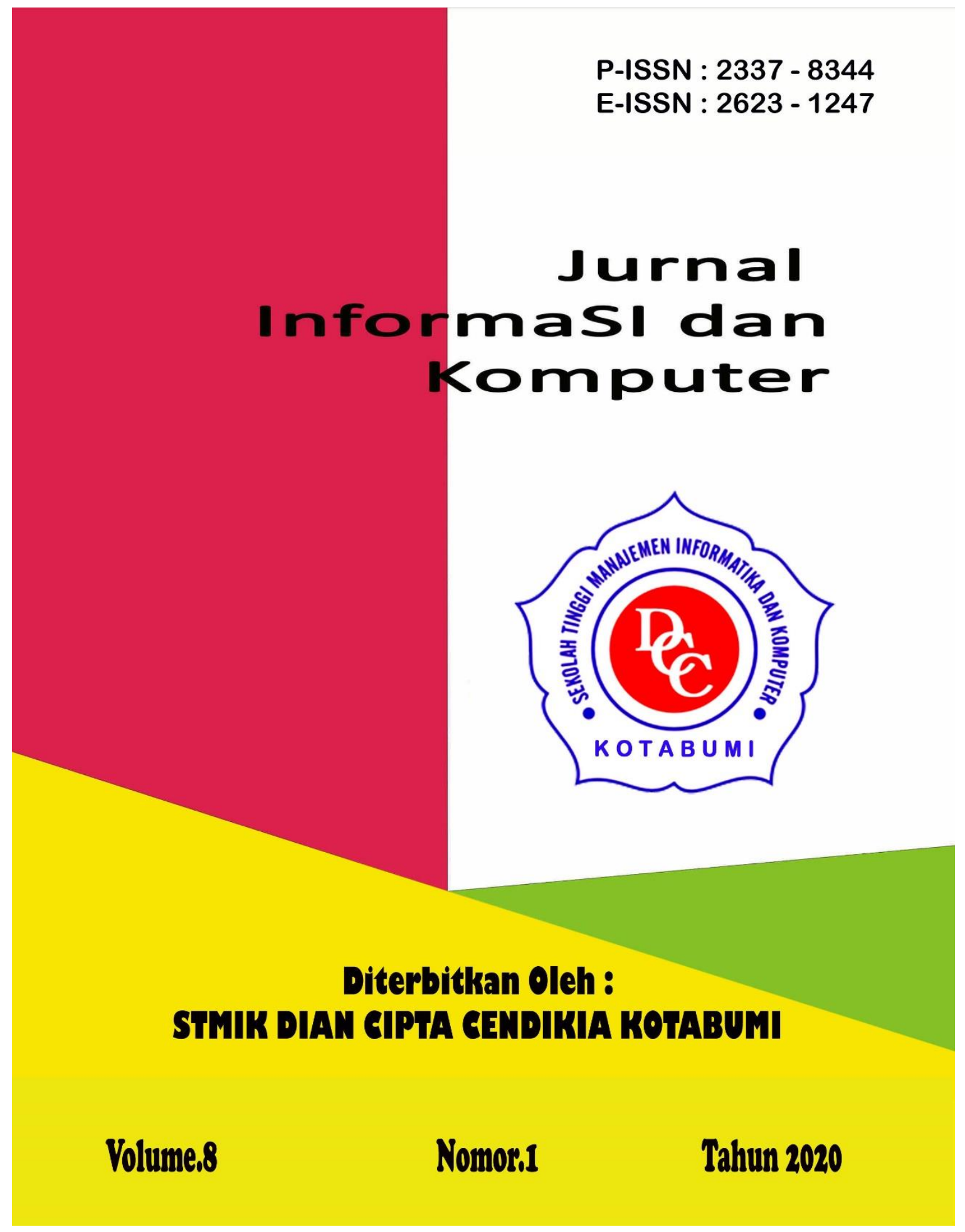




\section{Penerbit:}

STMIK DIAN CIPTA CENDIKIA KOTABUMI

Bekerjasama dengan LPPM STMIK DCC Kotabumi

Hak atas naskah/tulisan tetap berada pada penulis, isi diluar tanggung jawab

Penerbit dan Dewan Penyunting

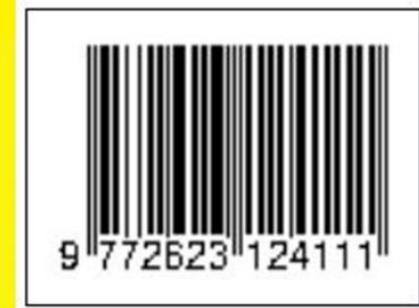




\section{PENGANTAR REDAKSI}

Puji syukur dipanjatkan kehadirat Tuhan Yang Maha Esa, atas karunia dan limpahan rahmatNYA jualah Jurnal Informatika dan komputer (InfoKom) STMIK Dian Cipta Cendikia Kotabumi ini dapat terwujud.Jurnal Informatika dan Komputer (InfoKom) yang terbit dua (2) kali dalam setahun ini merupakan suatu wadah untuk penyebar luasan hasil-hasil penelitian, studi pustaka, karya ilmiah yangberkaitan dengan Informatika dan Komputer khususnya bagi dosen-dosen STMIK Dian Cipta Cendikia Kotabumi serta umumnya para cendikiawan, praktisi, peneliti ilmu Informatika dan Komputer.

Harapan, dengan diterbitkannya Jurnal Informatika dan Komputer (InfoKom) ini sebagai salah satu bentuk sumbangan pemikiran dalam pengembangan ilmu informatika dan komputer yang berkaitan dengan kajian-kajian di bidang tekhnologi Informatik, Komunikasi Data dan Jaringan Komputer, perancangan dan Rekayasa Perangkat Lunak, serta ilmu-ilmu yang terkait dengan bidang Informatika dan Komputer lainnya.

Berkenaan dengan harapan tersebut, kepada para peneliti, dosen dan praktisi yang memiliki hasil-hasil penelitian, kajian pustaka, karya ilmiah dalam bidang tersebut diatas, dengan bangga redaksi Jurnal Informatika dan Komputer (JIK) menerima naskah ringkasan untuk dimuat pada jurnal Informatika dan Komputer (InfoKom) STMIK Dian Cipta Cendikia Kotabumi dengan berpedoman pada penulisan naskah jurnal sebagaimana dilampirkan pada halaman belakang (Bagian kulit dalam) buku jurnal ini.

Mutu dari suatu jurnal ilmiah tidak hanya ditentukan oleh para pengelolanya saja, tetapi para penulis dan pembaca jualah yang mempunyai peranan besar dalam meningkatkan mutu jurnal Informatika dan Komputer ini. Merujuk pada realita ini kamu sangat mengharapkan peran aktif dari peneliti untuk bersama-sama menjaga dan memelihara keberlangsungan dari jurnal Informatika dan Komputer STMIK Dian Cipta Cendikia Kotabumi ini. Yang juga tidak kalah pentingnya dari partisipasi tersebut diatas, adalah saran dan kritik yang membangun dari pembaca yang budiman agar kiranya dapat disampaikan langsung kepada redaksi JIK. Saran dan kritik yang membangun akan dijadikan masukan dan pertimbangan yang sangat berarti guna peningkatan mutu dan kualitas Jurnal Informatika dan Komputer STMIK Dian Cipta Cendikia Kotabumi.

Tak lupa diucapkan terima kasih yang tak terhingga atas perhatian dan kerjasama dari semua pihak yang tak dapat disebutkan satu persatu hingga dapat diterbitkan nya Jurnal Informatika dan Komputer (InfoKom) STMIK Dian Cipta Cendikia Kotabumi. Semoga apa yang telah diperbuat untuk kebaikan akan menjadi amal ibadah, amin.

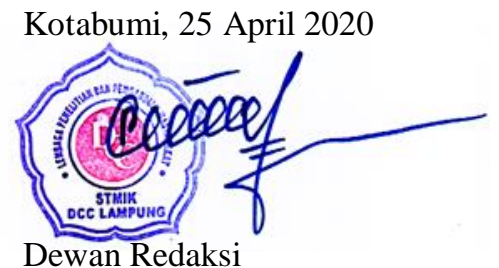




\section{JURNAL INFORMASI DAN KOMPUTER}

Volume 8 Nomor 1 April 2020

Jurnal Informasi dan Komputer merupakan Sarana informasi ilmu pengetahuan, Tekhnologi dan Komunikasi yang berupa hasil penelitian, tulisan ilmiah, Ataupun studi pustaka. Jurnal ini terbit dua kali setahun pada bulan April dan Oktober. Berisi hasil penelitian ilmiah di bidang informatika yang bertujuan untuk menghubungkan adanya kesenjangan antar kemajuan teknologi dan hasil penelitian. Jurnal ini di terbitkan pertama kali pada tahun 2013.

Penanggung Jawab:

Ketua STMIK Dian Cipta Cendikia

Kotabumi

\section{Pembina:}

Ketua STMIK Dian Cipta Cendikia

Kotabumi

Ketua Lembaga Penelitian STMIK Dian

Cipta Cendikia Kotabumi

\section{Pimpinan Redaksi}

Dwi Marisa Efendi,.S.Kom.,M.Ti

\section{Redaksi pelaksana}

Rustam,.S.Kom,.M.Ti (STMIK Dian

Cipta Cendikia Kotabumi)

Nurmayanti M.Kom (STMIK Dian

Cipta Cendikia Kotabumi)

Sukatmi,.S.Kom., M.Kom (AMIK DCC

Bandar Lampung)

Sampurna Dadi Riskiono,M.Kom

(Universitas Teknokrat Indonesia)

Ifo Wahyu

Pratama,S.Kom.,M.Ti(AMIK MASTER

Lampung)

\section{Mitra Bestari}

Merri Parida.,M.Kom (STMIK Dian

Cipta Cendikia Kotabumi)

Amarudin,S.Kom.,M.Eng (Universitas

Teknokrat Indonesia)

Didi Susianto.,S.T.,M.Kom (AMIK

DCC Bandar Lampung)

Alhibarsyah.,S.T.,M.Kom (Stmik Tunas

Bangsa Bandar Lampung)

Kemal Farouq Mauladi

.,S.Kom.,M.Kom (Universitas Islam

Lamongan)

Agus Setiawan S.Pd.,M.Eng

(Universitas Muhammadiyah

Lamongan)

Penerbit : STMIK Dian Cipta Cendikia Kotabumi Bekerja Sama Dengan LPPM STMIK Dian Cipta Cendikia Kotabumi.

\section{Alamat Redaksi/Penerbit:}

Jl. Negara No. 3 Candimas Kotabumi

Lampung Utara

No Telpon/Fax 072423003

Email : 1ppm-stmik@dcc.ac.id 


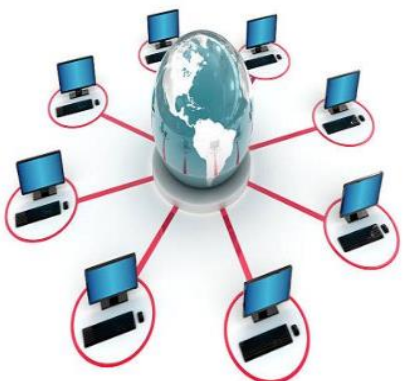 \\ JURNAL INFORMASI DAN KOMPUTER VOL. 8 NO. 1 THN. 2020}

\section{DAFTAR ISI}

\section{Halaman}

Sistem Pendukung Keputusan Penentuan Lahan Kopi Terbaik Dengan Metode

Ahp (Analytic Hierarchy Process)

Sidik Rahmatullah, Rendy Abdurahman (AMIKKOM Jogja,

STMIK Dian Cipta Cendikia Kotabumi)

Rancang Bangun Sistem Informasi Pada Program Pembangunan Pemberdayaan

Masyarakat Desa( P3md ) Berbasis Web Mobile

Ferly Ardhy, Firmansyah, Sidik Rahmatullah,(IIB Darma Jaya Bandar Lampung

STMIK Dian Cipta Cendikia Kotabumi, AMIKKOM Jogja)

Sistem Informasi Pengolahan Data Alumni Sekolah Menengah Atas (Sma)

Merri Parida, Nindiya Ova Rahmawati (AMIKKOM Jogja,

STMIK Dian Cipta Cendikia Kotabumi)

SISTEM INFORMASI GEOGRAFIS PUSKESMAS BESERTA SARANA

DAN PRASARANA BERBASIS WEB MOBILE

Nurmayanti, Windy Dwi Bahari (AMIKOM Jogja,

STMIK Dian Cipta Cendikia Kotabumi)

Rancang Bangun Sistem Informasi Konseling Untuk Sekolah Menengah Kejuruan

(Smk) Berbasis Website

Aliy Hafiz1, Galih Rakasiwi, Ifo Wahyu Pratama, Agus Komarudin,

Bambang Suparapto, Fathurrahman Kurniawan Ikhsan

(AMIK Dian Cipta Cendikia Bandar Lampung,

Universitas Nahdhatul Ulama Lampung, AMIK Dian Cipta Cendikia Pringsewu,

Universitas Mitra Indonesia, Lampung) .....

Sistem Pendukung Keputusan Pemilihan Driver Terbaik Menggunakan Metode

Weight Product (Wp)

Dina Lorenza, Pitrawati (STMIK Dian Cipta Cendikia Kotabumi

AMIK Dian Cipta Cendikia)

Rancang Bangun Sistem Informasi Pembayaran Mahasiswa

Darsin(Universitas Megou pak Tulang Bawang)

Sistem Informasi Geografis Bengkel Motor Honda Resmi Bandar Lampung

Sukatmi, Nuraini (AMIK Dian Cipta Cendikia Bandar Lampung).....

Sistem Pakar Diagnosa Penyakit Kulit Wajah Dengan Metode

Certainty Factor Pada Klinik Skin Rachel

Dwi Marisa Efendi, Putri Yulita Sari (IIB Darmajaya Bandar Lampung,

STMIK Dian Cipta Cendikia Kotabumi) 
Sistem Informasi Monitoring Siswa Pada Mts Al-Islamiah Bunut Kabupaten Pesawaran Yuli Syafitri ${ }^{2}$, Reni Astika ${ }^{1}$, Septian Hernando $^{3}$ AMIK Dian Cipta Cendikia

Aplikasi Kamus Bahasa Jepang Berbasis Mobile Android

Rustam $^{2}$, A Yanda Febry Pangestu ${ }^{2}$ Sistem Informasi, Teknologi Komputer ${ }^{1}$, IIB Darmajaya

Bandar Lampung ${ }^{2}$ STMIK Dian Cipta Cendikia Kotabumi 


\title{
SISTEM PENDUKUNG KEPUTUSAN PEMILIHAN DRIVER TERBAIK MENGGUNAKAN METODE WEIGHT PRODUCT (WP)
}

\author{
Dina Lorenza ${ }^{1}$, Pitrawati $^{2}$ \\ STMIK Dian Cipta Cendikia Kotabumi \\ AMIK Dian Cipta Cendikia, Bandar Lampung \\ E-mail : dinalorenza285@gmail.com¹, pitrawati@dcc.ac.id ${ }^{2}$
}

\begin{abstract}
ABSTRAK
Driver merupakan bagian terpenting dalam perusahaan jasa expedisi angkutan. Adanya driver terbaik yang berkualitas merupakan salah satu faktor pendukung yang sangat penting dalam perkembangan perusahaan. Salah satu metode yang baik dalam menentukan driver terbaik yaitu menggunakan metode weight product. Metode weight product adalah metode pengambilan keputusan menggunakan perkalian untuk menghubungkan nilai kriteria, yang dimana nilai untuk setiap kriteria harus dipangkatkan dengan bobot kriteria yang bersangkutan. Sistem pendukung keputusan ini merupakan salah satu alat yang dapat membantu pengambilan keputusan dalam penentuan driver terbaik secara komputerisasi agar lebih efektif dan efisien. Dari perhitungan menggunakan metode weight product dapat diketahui driver yang terbaik dari alternatif yang ada pada sebuah perusahaan. Hasil penelitian menunjukkan metode Weighted Product dalam sistem Pendukung Keputusan (SPK) sangat baik dalam memberikan rekomendasi dalam penentuan driver terbaik guna meningkatkan kinerja karyawan sedangakan hasil analisa yang dilakukan bagian HRD maka didapatkan penilaian berdasarkan perangkingan. Perangkingan tertinggi diperoleh oleh Anton Fatoni dengan nilai vektor sebesar 0.06436 dan berhak mendapatkan bonus dari Perusahaan.
\end{abstract}

Kata kunci : Sistem pendukung keputusan, Driver, Weight Product

Drivers are the most important part in a freight forwarding service company. The existence of the best quality drivers is one of the supporting factors that are very important in the development of the company. One good method of determining the best driver is to use the weight product method. Weight product method is a method of decision making using multiplication to link the value of criteria, where the value for each criterion must be raised with the weight of the criteria in question. This decision support system is one tool that can help decision making in determining the best computerized driver to be more effective and efficient. From calculations using the weight product method, it can be seen the best driver from the alternatives that exist in a company. The results showed the Weighted Product method in the Decision Support system (SPK) was very good in providing recommendations in determining the best driver to improve employee performance while the results of the analysis conducted by the HRD section obtained ratings based on ranking. The highest ranking is obtained by Anton Fatoni with a vector value of 0.06436 and is entitled to get a bonus from the Company

Keywords: Decision Support System, Driver, Weight Product.

\section{PENDAhUluan}

Driver merupakan bagian terpenting dalam perusahaan jasa expedisi angkutan. Adanya driver terbaik yang berkualitas merupakan salah satu faktor uta ma yang sangat penting dalam perkembangan perusahaan. Dengan adanya driver yang berkualitas akan membuat perusahaan jasa 
angkutan expedisi menjadi organisasi yang maju. Oleh karena itu, diperlukan manajemen driver dengan pemilihan driver terbaik untuk memacu semangat kerja driver dalam meningkatkan operasional, dedikasi dan kinerjanya sehingga menjadi lebih baik, lebih maju dan lebih berkembang.

Namun kendala yang dihadapi sebuah perusahaan penyelenggara jasa angkutan pada umumnya, masih belum optimal pemilihan driver terbaik dimana penilaian terhadap driver terbaik masih manual, penentuan driver terbaik ditentukan oleh seorang pimpinan dianggap tidak efektif dan efisien dalam pelaksanaan pemilihan driver terbaik, dan tanggung jawab dalam pekerjaan driver tersebut belum maksimal sehingga tidak terstruktur, hal ini disebabkan karena belum tersedianya lagi media yang memproses penilaian driver terbaik yang efektif.

Berdasarkan masalah tersebut, maka penulis mengembangkan sistem pendukung keputusan pemilihan pemilihan driver terbaik dengan membuat aplikasi Sistem Pendukung Keputusan penentuan driver terbaik dengan menggunakan metode Weight Product.

Adapun tujuan dari penulisan ini adalah sebagai berikut :

1. Untuk menghasilkan rancangan Sistem Pendukung Keputusan untuk menentukan driver terbaik berdasarkan metode Weight Product.

2. Menerapkan Metode weight product sebagai salah satu metode pemecahan masalah

3. Dapat membantu Pimpinan dalam proses menentukan driver terbaik.

\section{METODE PENELITIAN}

\subsection{Metode Penelitian}

Jenis penelitian yang digunakan adalah deskriptif. Penelitian deskriptif adalah survei, metode survei merupakan penyelidikan yang diadakan untuk memperoleh fakta-fakta dari gejala-gejala yang ada dan mencari keterangan-keterangan secara faktual baik tentang institusi sosial, ekonomi, atau politik dari suatu kelompok maupun suatu daerah (Nazir, 2014).

\subsection{Sistem Pendukung Keputusan}

Konsep Sistem Pendukung Keputusan (SPK) pertama kali diungkapkan pada awal tahun 1970-an oleh Michael S. Scott Morton dengan istilah
Management Decision System. Sistem tersebut adalah suatu sistem yang berbasis komputer yang ditunjukan untuk membantu pengambil keputusan dengan memanfaatkan data dan model tertentu untuk memecahkan berbagai persoalan yang tidak terstruktur

Menurut Turban, Sistem Pendukung Keputusan (SPK) merupakan sistem informasi yang berbasis komputer yang fleksibel, interaktif dan dapat diadaptasi, yang dikembangkan untuk mendukung solusi untuk masalah manajemen spesifik yang tidak terstruktur. Sistem Pendukung Keputusan menggunakan data, memberikan antarmuka pengguna yang mudah dan dapat menggabungkan pemikiran pengambilan

Menurut Tuban, Sistem Pendukung Keputusan atau Decision Support System (DSS) sebuah sistem yang digunakan sebagai alat bantu menyelesaikan masalah untuk membantu mengambil keputusan (manajer) dalam menentukan keputusan, tetapi tidak untuk menggantikan kapasitas manager, hanya memberikan pertimbangan.

Dari berbagai definisi diatas dapat dikatakan bahwa sistem pendukung keputusan merupakan sistem yang mampu memberikan penilaian terhadap alternatif guna untuk membantu para manajer dalam pengambilan keputusan.

\subsection{Metode Weighted Product (WP)}

Menurut Ningrum Weighted Product (WP) adalah keputusan analisis multi-kriteria yang populer dan merupakan metode pengambilan keputusan multikriteria. Weighted Product (WP) adalah himpunan berhingga dari alternatif keputusan yang dijelaskan dalam istilah beberapa kriteria keputusan.

Metode analisis data yang digunakan mengacu pada metode Weighted Product. Metode Weighted Product adalah salah satu metode pengambilan keputusan yang lebih efisien dan waktu yang dibutuhkan dalam perhitungan lebih singkat dan digunakan untuk menyelesaikan suatu masalah dengan menggunakan perkalian untuk menghubungkan nilai kriteria, yang dimana nilai untuk setiap kriteria harus dipangkatkan dulu dengan bobot kriteria yang bersangkutan. Proses ini sama seperti proses normalisasi.

Pemilihan metode Weighted Product (WP) didasarkan juga atas kemampuannya dalam memberikan solusi optimal dalam system pemeringkatan. Pemilihan metode ini juga didasarkan atas kompleksitas komputasi yang tidak terlalu sulit sehingga waktu yang dibutuhkan dalam menghasilkan perhitungan relatif singkat. 
Berikut adalah ciri khas perhitungan metode Weighted Product (WP) :

a. Metode Weighted Product (WP) menggunakan perkalian untuk menghubungkan rating atribut, dimana rating setiap atribut harus dipangkatkan dulu dengan bobot atribut yang bersangkutan.

b. Proses ini sama halnya dengan proses normalisasi.

c. Preferensi untuk alternatif $A_{i}$ diberikan sebagai berikut :

1. Penentuan nilai bobot $\mathrm{W}$

$$
W_{j}=\frac{W_{j}}{\sum W_{j}}
$$

$W_{j}$ adalah pangkat bernilai positif untuk atribut keuntungan, dan pankat bernilai negative untuk atribut biaya.

2. Penentuan nilai bobot $S$

$$
S_{i}=\prod_{j=1}^{n} X_{i j}^{W_{j}}
$$

Dimana $S_{i}$ adalah Hasil normalisasi keputusan pada alternatif ke-i, $X_{i j}$ adalah Rating Alternatif per artibut, $i$ adalah alternatif, $j$ adalah atribut, dan $\prod_{j=1}^{n} X_{i j}$ adalah Perkalian rating alternative per atribut dari $\mathrm{j}=1-\mathrm{n}$, Pada alternatif ini dimana $\Sigma W_{j}=1$.

3. Penentuan nilai bobot $\mathrm{V}$

$$
V_{i}=\frac{\prod_{j=1}^{n} X_{i j}^{W_{j}}}{\prod_{j=1}^{n} X_{i j} * W_{j}}
$$

Dimana, $V_{i}$ merupakan hasil preferensi alternatif ke $-\mathrm{i}$ dan $\prod_{j=1}^{n} X_{i j} *$ $W_{j}$ merupakan perjumlahan hasil perkalian rating alternatif per atribut.

Sederhananya seperti :

$V_{1}=\frac{S_{1}}{S_{1}+S_{2}+S_{3}}$

Keterangan :

$S$ = Preferensi alternative, dianalogikan sebagai vector $\mathrm{S}$.

$V=$ Preferensi alternative, dianalogikan sebagai vector $\mathrm{V}$.

$X=$ Nilai Kriteria

$W=$ Bobot criteria

$i=$ Alternatif

$j=$ Kriteria

$n$ = Banyaknya Kriteria

Pada metode yang digunakan ada kriteria dan bobot yang dibutuhkan untuk menentukan Driver Terbaik. Adapun kriterianya sebagai berikut:

$$
\begin{aligned}
& \text { C1 }=\text { Kedisplinan } \\
& \text { C2 }=\text { Kerjasama Team } \\
& \text { C3 }=\text { Prilaku } \\
& \text { C4 }=\text { Skill } \\
& \text { C5 }=\text { Ritase Perbulan } \\
& \text { C6 }=\text { Masa Kerja }
\end{aligned}
$$

Menentukan pembobotan nilai dalam hal ini berarti nilai pada setiap aspek penilaian kriteria akan dikategorikan menjadi bobot tertentu. Pada tahap ini dari masing-masing kriteria tersebut akan ditentukan bobot-bobotnya.

\subsection{Teknik Pengumpulan Data}

Teknik Pengumpulan Data yang digunakan dalam penelitian ini sebagai berikut :
a. Wawancara
b. Pengamatan/Observasi
c. Studi Kepustakaan

\subsection{Metode Pengembangan Sistem}

\subsubsection{Extreme Programming (XP)}

Menurut R.S. Pressman Extreme Programming (XP) merupakan salah satu metode pengembangan sistem yang berorientasi objek. Paradigma pembangunan mencakup seperangkat aturan dan praktik yang terjadi dalam kontekskerangka empat kegiatan yaitu: perencanaan, desain, coding, dan pengujian. Keempat aktivitas inilah yang akan menghasilkan sebuah perangkat lunakyang didasari dengan konsep model Extreme Programming

\subsubsection{Tahapan Extreme Programming (XP)}

Gambar dibawah ini selain memberikan kesimpulan bagaimana penggunaan Extreme Programming, akan dijelaskan mengenai empat konteks tersebut secara lebih detail. Berikut adalah tahapan-tahapan dalam kerangka kerja Extreme Programming.

Tahapan-tahapan dari Extreme Programming terdiri dari planning seperti memahami kriteria pengguna dan perencanaan pengembangan, designing seperti perancangan prototype dan tampilan, coding termasuk pengintegrasian, dan yang terakhir adalah testing.Langkah-langkah pengembangan dalam extreme programming adalah sebagai berikut:

\section{Planning}

Dalam tahap ini dikumpulkan kebutuhan awal user atau dalam XP disebut user stories. Hal ini 
dibutuhkan agar pengembang mengerti bisnis konten, kebutuhan output sistem, dan fitur utama dari software yang dikembangkan. Tahapan ini untuk menganalisa kebutuhan dari sistem tersebut untuk dapat digunakan sesuai dengan user requirement atau user stories di bidang penilaian kinerja driver.

\section{Analisis}

Dalam pembuatan sistem yang menggunakan metode XP (Extreme Programming), pada tahap analisis dilakukan pengumpulan kebutuhan awal user. Kebutuhan awal user adalah membangun sistem yang dapat melakukan perhitungan penentuan driver terbaik dengan menggunakan metode WP(Weight Product) serta memberikan informasi factor kriteria.

\subsection{Kriteria Penilaian}

Pada Tahap ini perlu dilakukan pembuatan struktur kreteria dan pembobotan yang dibutuhkan untuk melakukan penilaian untuk menentukan Driver terbaik. Adapun struktur kreteria dalam penentuan driver terbaik adalah sebagai berikut :

Tabel 1. Kriteria Driver Terbaik

\begin{tabular}{|c|l|c|}
\hline Kode & Nama Kreteria & Katagori \\
\hline C1 & Kedisiplinan & Benefit \\
\hline C2 & Kerjasama Team & Benefit \\
\hline C3 & Perilaku & Benefit \\
\hline C4 & Skill & Benefit \\
\hline C5 & Ritase Perbulan & Benefit \\
\hline C6 & Masa Kerja & Benefit \\
\hline
\end{tabular}

Menentukan pembobotan nilai dalam hal ini berarti nilai pada setiap aspek penilaian kriteria akan dikategorikan menjadi bobot tertentu. Pada tahap ini dari masing-masing kriteria tersebut akan ditentukan bobot-bobotnya.

Tabel 2. Bobot Kreteria

\begin{tabular}{|c|c|}
\hline Kode & Bobot \\
\hline $\mathrm{C} 1$ & $20 \%$ \\
\hline $\mathrm{C} 2$ & $15 \%$ \\
\hline $\mathrm{C} 3$ & $20 \%$ \\
\hline $\mathrm{C} 4$ & $15 \%$ \\
\hline $\mathrm{C} 5$ & $20 \%$ \\
\hline $\mathrm{C} 6$ & $10 \%$ \\
\hline
\end{tabular}

Pada Tabel 2. menyatakan nilai bobot setiap kreteria yang sudah ada ditentukan oleh pihak perusahaan dalam hal ini adalah Pimpinan.

Dari masing-masing kriteria pada tabel di atas akan ditentukan bobot-bobot masing-masing kriteria. Bobot terdiri dari lima bilangan fuzzy yaitu sangat rendah (SR), rendah $(\mathrm{R})$, sedang $(\mathrm{S})$, tinggi (T), sangat tinggi (ST) seperti terlihat pada gambar berikut :

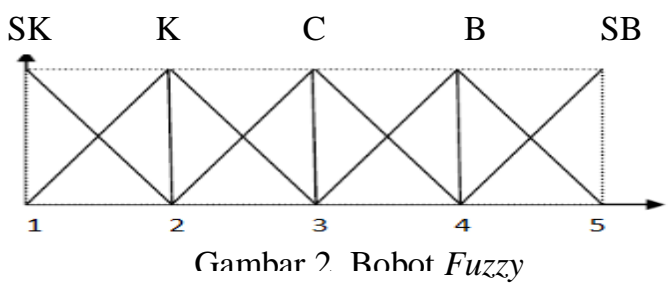

Keterangan :

SK = Sangat Kurang

$\mathrm{K}$ = Kurang

$\mathrm{C}$ = Cukup

$\mathrm{B}=$ Baik

$\mathrm{SB}=$ Sangat Baik

Bilangan Fuzzy dikonversikan ke bilangan crisp seperti pada tabel dibawah ini :

Tabel 3. Bilangan crisp

\begin{tabular}{|c|l|c|}
\hline No & \multicolumn{1}{|c|}{ Bobot Fuzzy } & Bilangan Crips \\
\hline 1 & Sangat Kurang (SK) & 1 \\
\hline 2 & Kurang (K) & 2 \\
\hline 3 & Cukup (C) & 3 \\
\hline 4 & Baik (B) & 4 \\
\hline 5 & Sangat Baik (SB) & 5 \\
\hline
\end{tabular}

\subsection{Design}

Pada proses design dilakukan pada proses alur kerja system, tahap-tahap pengerjaan system dan tahap-tahap berjalannya system dengan baik serta user interface. Design proses alur kerja dan user interface akan disajikan menggunakan alat pengembangan system seperti Use Case, Activity Diagram dan Class Diagram.

\subsection{Use Case}

Diagram use case merupakan suatu penggambaran hak akses yang dilakukan oleh aktor terhadap sistem yang dirancang. 


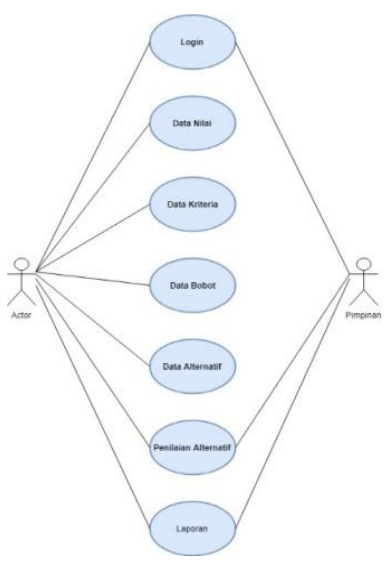

Gambar 3. Use Case

\subsection{Class Diagram}

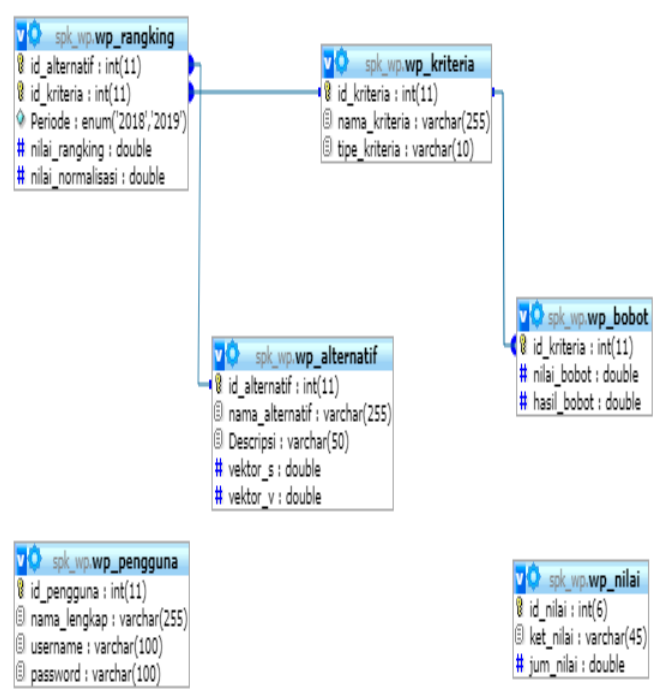

Gambar 4. Class Diagram

\section{HASIL DAN PEMBAHASAN}

\subsection{Hasil}

1. Menu Login

Halaman Login menampilkan halaman login yang ada dalam program berupa login pengguna

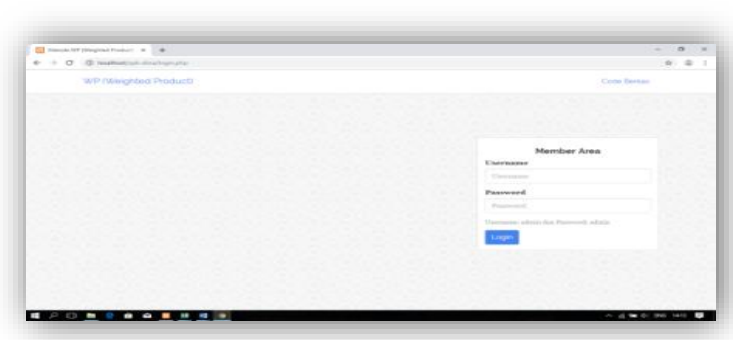

Gambar 5. Menu Login

2. Menu Home

Halaman Home menampilkan gambaran umum program yang ada dalam program berupa laporan dalam bentuk grafik

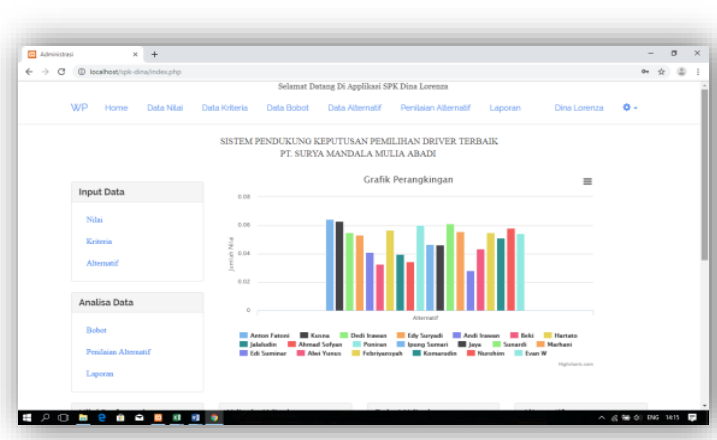

Gambar 6. Menu Home

3. Menu Tambah Data Nilai.

Menu ini memungkinkan penginputan nilai preferensi berdasarkan hasil di lapangan dan berdasarkan preferensi masing masing

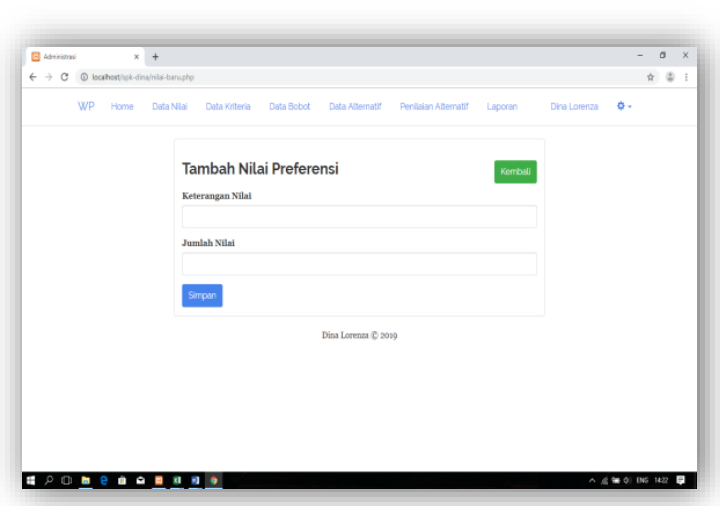

Gambar 7. Menu Tambah Nilia Preferensi.

4. Menu Tambah Data Kriteria Menu ini di siapkan jika ada penambahan kriteria pada system jika di perlukan oleh pengguna.

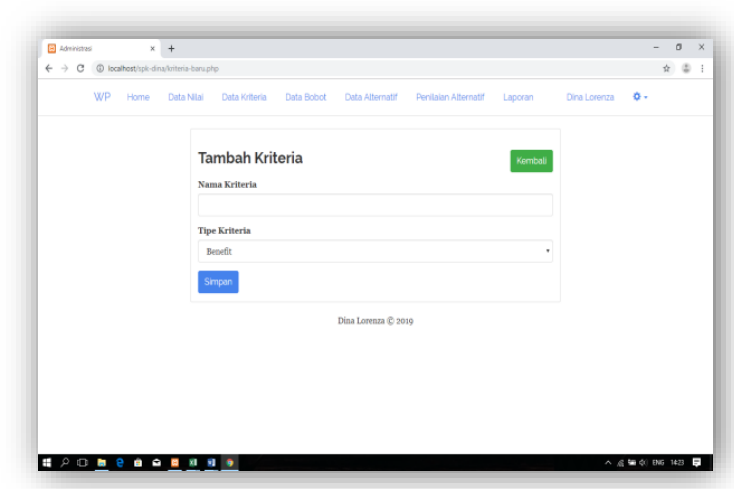

Gambar 8. Menu Tambah Data Kriteria

5. Menu Tambah Bobot Menu ini memungkinkan user melakukan penambahan bobot pada masing masing kriteria. 


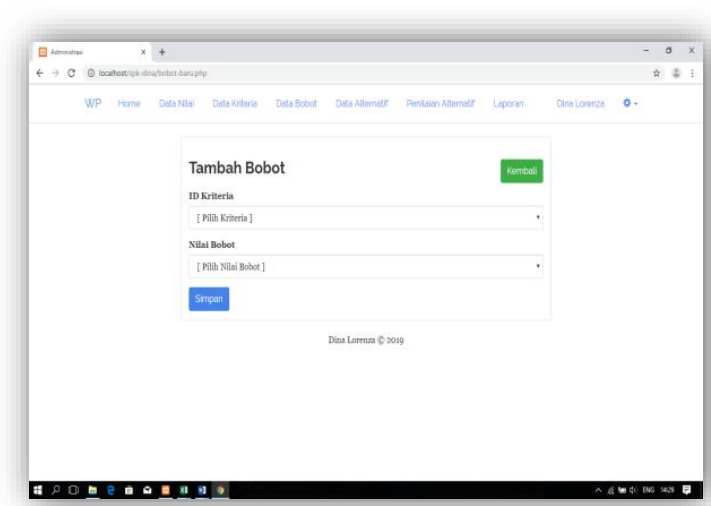

Gambar 9. Menu Tambah Bobot

6. Menu Data Alternatif

Menu ini adalah menu untuk menambahkan kemungkinan alternatif yang muncul untuk di tambahkan

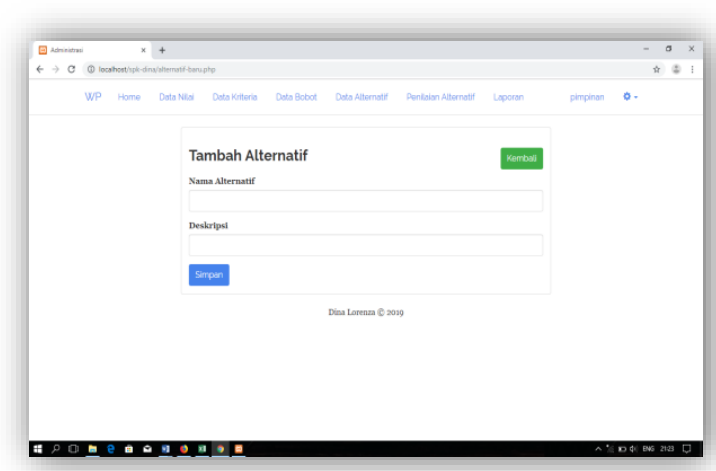

Gambar 10. Menu Data Alternatif

7. Menu Tambah Penilaian Alternatif.

Menu ini memungkinkan penginputan nilai berdasarkan hasil di lapangan dan berdasarkan kriteria masing masing.

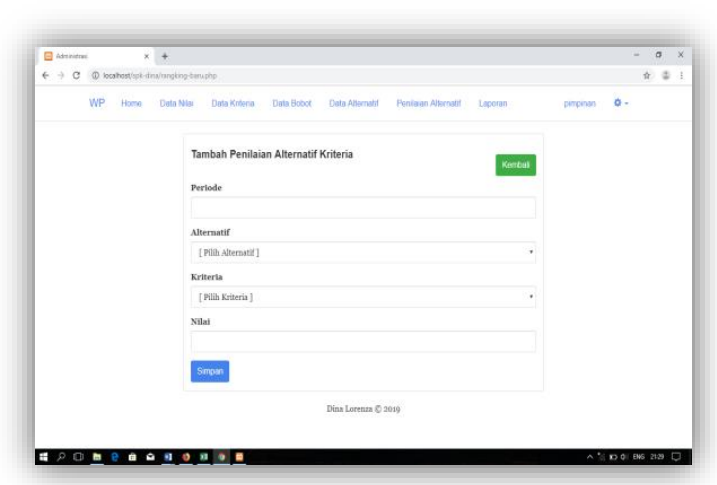

Gambar 11. Menu Tambah Penilaian Alternatif.

8. Menu Laporan PDF

Menu ini memungkinkan menampilkan laporan nilai berdasarkan hasil di lapangan dan berdasarkan criteria masing masing dalam bentuk pdf di komputer

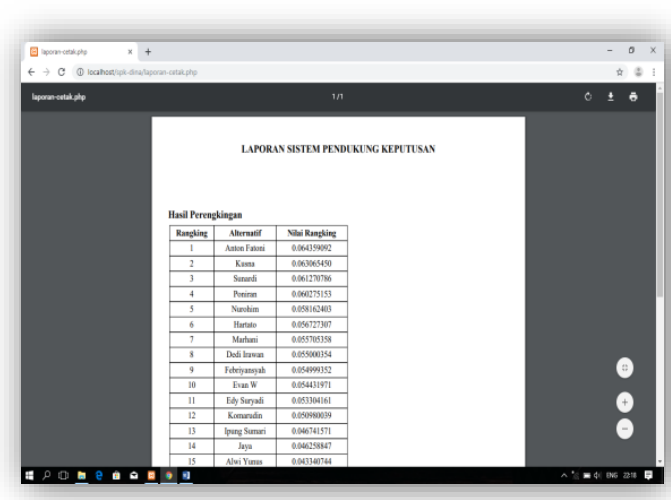

Gambar 12. Menu Laporan PDF

Dalam pembuatan sistem yang menggunakan metode XP (Extreme Programming), pada tahap analisis dilakukan pengumpulan kebutuhan awal user. Kebutuhan awal user adalah membangun sistem yang dapat melakukan perhitungan penentuan driver terbaik dengan menggunakan metode WP (Weight Product) serta memberikan informasi factor kriteria.

\subsection{Pembahasan}

\subsubsection{Perhitungan Metode WP}

Penilaian Alternatif per Kreteria

Tabel 4. Penilaian Alternatif per Kreteria

\begin{tabular}{|l|c|c|c|c|c|c|}
\hline \multirow{2}{*}{ Alternatif } & \multicolumn{7}{|c|}{ Kriteria } \\
\cline { 2 - 7 } & C1 & C2 & C3 & C4 & C5 & C6 \\
\hline $\begin{array}{l}\text { Anton } \\
\text { Fatoni }\end{array}$ & 97 & 100 & 91 & 100 & 100 & 60 \\
\hline Kusna & 97 & 80 & 89 & 80 & 100 & 100 \\
\hline $\begin{array}{l}\text { Dedi } \\
\text { Irawan }\end{array}$ & 73 & 80 & 86 & 93 & 80 & 60 \\
\hline $\begin{array}{l}\text { Edy } \\
\text { Suryadi }\end{array}$ & 80 & 92 & 74 & 93 & 80 & 40 \\
\hline $\begin{array}{l}\text { Andi } \\
\text { Irawan }\end{array}$ & 63 & 48 & 57 & 67 & 60 & 60 \\
\hline Beki & 37 & 64 & 57 & 27 & 40 & 100 \\
\hline Hartato & 83 & 96 & 77 & 93 & 80 & 60 \\
\hline Jalaludin & 80 & 68 & 57 & 33 & 40 & 100 \\
\hline $\begin{array}{l}\text { Ahmad } \\
\text { Sofyan }\end{array}$ & 60 & 56 & 54 & 73 & 40 & 20 \\
\hline Poniran & 93 & 92 & 91 & 100 & 80 & 60 \\
\hline $\begin{array}{l}\text { Ipung } \\
\text { Sumari }\end{array}$ & 87 & 88 & 77 & 80 & 60 & 20 \\
\hline Jaya & 80 & 56 & 57 & 67 & 60 & 100 \\
\hline Sunardi & 93 & 100 & 91 & 73 & 80 & 100 \\
\hline Marhani & 73 & 88 & 74 & 80 & 80 & 100 \\
\hline $\begin{array}{l}\text { Edi } \\
\text { Suminar }\end{array}$ & 37 & 32 & 57 & 20 & 40 & 100 \\
\hline $\begin{array}{l}\text { Alwi } \\
\text { Yunus }\end{array}$ & 63 & 56 & 49 & 73 & 60 & 100 \\
\hline & & & & & & \\
\hline
\end{tabular}




\begin{tabular}{|l|c|c|c|c|c|c|}
\hline $\begin{array}{l}\text { Febriansya } \\
\text { h }\end{array}$ & 77 & 88 & 83 & 100 & 60 & 80 \\
\hline Komarudin & 83 & 60 & 77 & 73 & 80 & 60 \\
\hline Nurohim & 93 & 76 & 89 & 73 & 100 & 60 \\
\hline Evan W & 97 & 96 & 80 & 80 & 60 & 60 \\
\hline
\end{tabular}

$\left(100^{0,15}\right)\left(100^{0,20}\right)\left(60^{0,10}\right)$

$\mathrm{S}_{1}=2,49663 \times 1,99526 \times 2,46495 \times 1,99526$ x 2,51189 x 1,50597 $=92,67823$

$\mathrm{A}_{2}$ (Kusna) $=\left(97^{0,20}\right)\left(80^{0,15}\right)\left(89^{0,20}\right)\left(80^{0,15}\right)$ $\left(100^{0,20}\right)\left(100^{0,10}\right)$

\subsubsection{Penilaian Bobot Kriteria}

Tabel 5. Bobot Kriteria

\begin{tabular}{|l|c|}
\hline \multicolumn{1}{|c|}{ Kriteria } & Bobot \\
\hline Kediplinan & $20 \%$ \\
\hline Kerjasama Team & $15 \%$ \\
\hline Perilaku & $20 \%$ \\
\hline Skill & $15 \%$ \\
\hline Retase Per Bulan & $20 \%$ \\
\hline Masa Kerja & $10 \%$ \\
\hline
\end{tabular}

1. Perhitungan Perbaikan Bobot Kriteria dengan persamaan sebagai berikut :

$$
W_{j}=\frac{W_{j}}{\sum W_{j}}
$$

$W_{1}$

$$
\begin{aligned}
& =\frac{0,20}{0,20+0,15+0,20+0,15+0,20+0,10} \\
& =0,20
\end{aligned}
$$

$W_{2}$

$$
\begin{aligned}
& =\frac{0,15}{0,20+0,15+0,20+0,15+0,20+0,10} \\
& =0,15
\end{aligned}
$$

$W_{3}$

$$
\begin{aligned}
& =\frac{0,20}{0,20+0,15+0,20+0,15+0,20+0,10} \\
& =0,20 \\
& W_{4}
\end{aligned}
$$$$
=\frac{0,15}{0,20+0,15+0,20+0,15+0,20+0,10}
$$$$
=0,15
$$

$W_{5}$

$$
\begin{aligned}
& =\frac{0,20}{0,20+0,15+0,20+0,15+0,20+0,10} \\
& =0,20
\end{aligned}
$$

$$
\begin{aligned}
& W_{6} \\
& =\frac{0,10}{0,20+0,15+0,20+0,15+0,20+0,10} \\
& =0,10
\end{aligned}
$$

2. Menghitung vektor $S$. langkah ini sama seperti proses normalisasi, dengan persamaan berikut:

$\mathrm{A}_{1}($ Anton Fatoni $)=\left(97^{0,20}\right)\left(100^{0,15}\right)\left(91^{0,20}\right)$

$\mathrm{S}_{2}=2,49663 \times 1,92958 \times 2,45402 \times 1,92958$

x 2,51189 x 1,58489 $=90,81537$

$\mathrm{A}_{3}$ (Dedi Irawan $)=\left(73^{0,20}\right)\left(80^{0,15}\right)\left(86^{0,20}\right)$ $\left(93^{0,15}\right)\left(80^{0,20}\right)\left(60^{0,10}\right)$

$\mathrm{S}_{3}=2,35866 \times 1,92958 \times 2,43725 \times 1,97366$ x 2,40225 x 1,50597

$$
=79,20149
$$

$\mathrm{A}_{4}($ Edy Suryadi $)=\left(80^{0,20}\right)\left(92^{0,15}\right)\left(74^{0,20}\right)$ $\left(93^{0,15}\right)\left(80^{0,20}\right)\left(40^{0,10}\right)$

$\mathrm{S}_{4}=2,40225 \times 1,97046 \times 2,36508 \times 1,97366$ x 2,40225 x 1,44613

$$
=76,75894
$$

$\mathrm{A}_{5}$ (Andi Irawan) $=\left(63^{0,20}\right)\left(48^{0,15}\right)\left(57^{0,20}\right)$ $\left(67^{0,15}\right)\left(60^{0,20}\right)\left(60^{0,10}\right)$

$\mathrm{S}_{5}=2,29017 \times 1,78725 \times 2,24479 \times 1,87893$ $\mathrm{x} 2,26793 \times 1,50597$

$$
=58,96385
$$

$\mathrm{A}_{6}(\mathrm{Beki})=\left(37^{0,20}\right)\left(64^{0,15}\right)\left(57^{0,20}\right)\left(27^{0,15}\right)$ $\left(40^{0,20}\right)\left(100^{0,10}\right)$

$\mathrm{S}_{6}=2,29017 \times 1,78725 \times 2,24479 \times 1,87893$

x $2,26793 \times 1,50597$ $=58,96385$

$\mathrm{A}_{7}($ Hartato $)=\left(83^{0,20}\right)\left(96^{0,15}\right)\left(77^{0,20}\right)\left(93^{0,15}\right)$ $\left(80^{0,20}\right)\left(60^{0,10}\right)$

$\mathrm{S}_{7}=2,42000 \times 1,98308 \times 2,38396 \times 1,97366$ x 2,40225 x 1,50597

$$
=81,68833
$$

$\mathrm{A}_{8}($ Jalaludin $)=\left(80^{0,20}\right)\left(68^{0,15}\right)\left(57^{0,20}\right)\left(33^{0,15}\right)$ $\left(40^{0,20}\right)\left(100^{0,10}\right)$

$\mathrm{S}_{8}=2,40225 \times 1,88311 \times 2,24479 \times 1,68957$ x $2,09128 \times 1,58489$

$$
=56,86675
$$

$\mathrm{A}_{9}($ Ahmad Sofyan $)=\left(60^{0,20}\right)\left(56^{0,15}\right)\left(54^{0,20}\right)$ $\left(73^{0,15}\right)\left(40^{0,20}\right)\left(20^{0,10}\right)$

$\mathrm{S}_{9}=2,26793 \times 1,82906 \times 2,22064 \times 1,90326$ x 2,09128 x 1,34928

$$
=49,47099
$$

$\mathrm{A}_{10}($ Poniran $)=\left(93^{0,20}\right)\left(92^{0,15}\right)\left(91^{0,20}\right)$

$\left(100^{0,15}\right)\left(80^{0,20}\right)\left(60^{0,10}\right)$

$\mathrm{S}_{10}=2,47569 \times 1,97046 \times 2,46495 \times 1,99526$

x 2,40225 x 1,50597

$$
=86,79729
$$


$\mathrm{A}_{11}$ (Ipung Sumari) $=\left(87^{0,20}\right)\left(88^{0,15}\right)\left(77^{0,20}\right)$ $\left(80^{0,15}\right)\left(60^{0,20}\right)\left(20^{0,10}\right)$

$\mathrm{S}_{11}=2,44289 \times 1,95737 \times 2,38396 \times 1,92958$ x $2,26793 \times 1,34928$

$$
=67,30869
$$

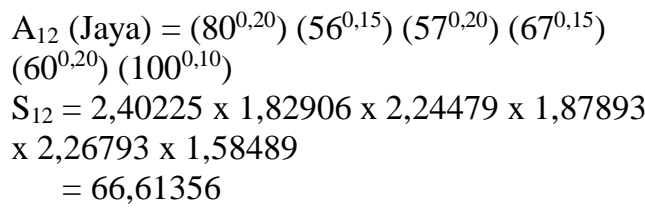

$A_{13}($ Sunardi $)=\left(93^{0,20}\right)\left(100^{0,15}\right)\left(91^{0,20}\right)$ $\left(73^{0,15}\right)\left(80^{0,20}\right)\left(100^{0,10}\right)$

$\mathrm{S}_{13}=2,47569 \times 1,99526 \times 2,46495 \times 1,90326$ x 2,40225 x 1,58489

$$
=88,23102
$$

$\mathrm{A}_{14}$ (Marhani) $=\left(73^{0,20}\right)\left(80^{0,15}\right)\left(86^{0,20}\right)\left(93^{0,15}\right)$ $\left(80^{0,20}\right)\left(60^{0,10}\right)$

$\mathrm{S}_{14}=2,35866 \times 1,95737 \times 2,36508 \times 1,92958$ x $2,40225 \times 1,58489$

$$
=80,21670
$$

$\mathrm{A}_{15}$ (Edi Suminar $)=\left(37^{0,20}\right)\left(32^{0,15}\right)\left(57^{0,20}\right)$ $\left(20^{0,15}\right)\left(40^{0,20}\right)\left(100^{0,10}\right)$

$\mathrm{S}_{15}=2,05892 \times 1,68179 \times 2,24479 \times 1,56731$ x 2,09128 x 1,58489

$$
=40,37888
$$

$\mathrm{A}_{16}$ (Alwi Yunus) $=\left(63^{0,20}\right)\left(56^{0,15}\right)\left(49^{0,20}\right)$ $\left(73^{0,15}\right)\left(60^{0,20}\right)\left(100^{0,10}\right)$

$\mathrm{S}_{16}=2,29017 \times 1,82906 \times 2,17791 \times 1,90326$ x $2,26793 \times 1,58489$

$$
=62,41144
$$

$A_{17}($ Febriansyah $)=\left(77^{0,20}\right)\left(88^{0,15}\right)\left(83^{0,20}\right)$ $\left(100^{0,15}\right)\left(60^{0,20}\right)\left(80^{0,10}\right)$

$\mathrm{S}_{17}=2,38396 \times 1,95737 \times 2,42000 \times 1,99526$ x 2,26793 x 1,54992

$$
=79,20004
$$

$\mathrm{A}_{18}($ Komarudin $)=\left(83^{0,20}\right)\left(60^{0,15}\right)\left(77^{0,20}\right)$ $\left(73^{0,15}\right)\left(80^{0,20}\right)\left(60^{0,10}\right)$

$\mathrm{S}_{18}=2,42000 \times 1,84809 \times 2,38396 \times 1,90326$ x 2,40225 x 1,50597

$$
=73,41216
$$

$\mathrm{A}_{19}$ (Nurohim) $=\left(93^{0,20}\right)\left(76^{0,15}\right)\left(89^{0,20}\right)$ $\left(73^{0,15}\right)\left(100^{0,20}\right)\left(60^{0,10}\right)$

$\mathrm{S}_{19}=2,47569 \times 1,91479 \times 2,45402 \times 1,90326$ x 2,51189 x 1,50597

$$
=83,75489
$$

$\mathrm{A}_{20}($ Evan W $)=\left(97^{0,20}\right)\left(96^{0,15}\right)\left(80^{0,20}\right)\left(80^{0,15}\right)$ $\left(60^{0,20}\right)\left(60^{0,10}\right)$

$\mathrm{S}_{20}=2,49663 \times 1,98308 \times 2,40225 \times 1,92958$

x $2,26793 \times 1,50597$

$=78,38300$
3. Menghitung vektor $\mathrm{V}$, atau preferensi relatif dari setiap alternatif, untuk perangkingan dengan persamaan berikut:

$V_{1}=\frac{S 1}{S 1+S 2+S 3+S 4+S 5+S 6}$

$$
\begin{aligned}
& \text { V1 } \\
& =\frac{92,67823}{1440,01774} \\
& =0,06436 \\
& =\frac{90,81537}{1440,01774} \\
& =\quad \mathbf{0 , 0 6 3 0 7}
\end{aligned}
$$

V4

$\begin{aligned}(\text { Edy Suryadi }) & =\frac{76,75894}{1440,01774} \\ & =\mathbf{0 , 0 5 3 3 0}\end{aligned}$

V5

(Andi Irawan) $=\frac{58,96385}{1440,01774}$

$=\mathbf{0 , 0 4 0 9 5}$

V6 $\left(\right.$ Beki) $\quad=\frac{46,86611}{1440,01774}$

$=\mathbf{0 , 0 3 2 5 5}$

$\mathrm{V7}($ Hartato $) \quad=\frac{81,68833}{1440,01774}$

$=\mathbf{0 , 0 5 6 7 3}$

$\mathrm{V} 8$ (Jalaludin $) \quad=\frac{56,86675}{1440,01774}$

$=\mathbf{0 , 0 3 9 4 9}$

V9 (Ahmad

Sofyan)

$=\frac{49,47099}{1440,01774}$

$\mathrm{V} 10$ (Poniran) $=\frac{\mathbf{0 , 0 3 4 3 5}}{\frac{86,79729}{1440,01774}}$

V11 (Ipung

Sumari)

$=\mathbf{0 , 0 6 0 2 8}$

\begin{tabular}{ll} 
& \multicolumn{1}{c}{1440,01774} \\
V12 (Jaya) & $=\frac{\mathbf{0 , 0 4 6 7 4}}{66,61356}$ \\
& $=c, 0,01746$ \\
V13 (Sunardi) & $=\frac{88,23102}{1440,01774}$ \\
& $=\quad \mathbf{0 , 0 6 1 2 7}$
\end{tabular}

V14

(Marhani)

$$
\begin{array}{cc}
= & \frac{80,21670}{1440,01774} \\
= & \mathbf{0 , 0 5 5 7 1}
\end{array}
$$

V15 (Edi

Suminar) 


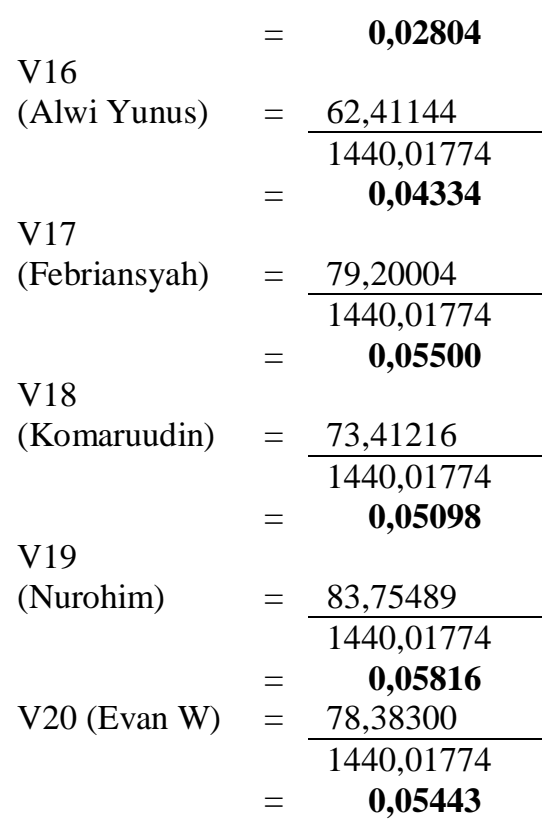

Tabel 6. Perhitungan Metode WP

\begin{tabular}{|c|l|c|}
\hline \multicolumn{3}{|c|}{ Perhitungan Metode WP } \\
\hline Rangking & Nama Driver & Nilai V \\
\hline V1 & Anton Fatoni & 0,06436 \\
\hline V2 & Kusna & 0,06307 \\
\hline V3 & Dedi Irawan & 0,05500 \\
\hline V4 & Edy Suryadi & 0,05330 \\
\hline V5 & Andi Irawan & 0,04095 \\
\hline V6 & Beki & 0,03255 \\
\hline V7 & Hartato & 0,05673 \\
\hline V8 & Jalaludin & 0,03949 \\
\hline V9 & Ahmad Sofyan & 0,03435 \\
\hline V10 & Poniran & 0,06028 \\
\hline V11 & Ipung Sumari & 0,04674 \\
\hline V12 & Jaya & 0,04626 \\
\hline V13 & Sunardi & 0,06127 \\
\hline V14 & Marhani & 0,05571 \\
\hline V15 & Edi Suminar & 0,02804 \\
\hline V16 & Alwi Yunus & 0,04334 \\
\hline V17 & Febriansyah & 0,05500 \\
\hline V18 & Komarudin & 0,05098 \\
\hline V19 & Nurohim & 0,05816 \\
\hline V20 & Evan W & 0,05443 \\
\hline
\end{tabular}

Tabel berikut merupakan hasil ranking driver terbaik dengan metode weight product. Driver yang memiliki nilai preferensi tertinggi atau rangking 1 adalah Anton Fatoni dengan nilai akhir 0,06436 dan karyawan yang memiliki nilai preferensi terendah atau rangking 20 adalah Edi Suminar dengan nilai akhir 0,02804.

\section{KESIMPULAN}

Hasil penelitian menunjukkan metode Weighted Product dalam sistem Pendukung Keputusan (SPK) sangat baik dalam memberikan rekomendasi dalam penentuan driver terbaik guna meningkatkan kinerja karyawan. Perpaduan SPK tentunya membutuhkan preferensi khusus pada kasus dan tujuan yang ingin dicapai. Dalam pengembangan sistem SPK, penentuan keputusan tetaplah berada dalam wilayah Pimpinan sehingga fungsionalitas sistem yang dibangun haruslah memberikan otoritas seorang pimpinan dalam memberikan keputusan, sebagaimana aplikasi yang dirancang dalam SPK ini, HRD sebagai penentu jumlah kuota yang ditentukan. Dengan pengembangan SPK pemberian penilaian driver ini dapat menjadi alat bantu bagi pengambil kebijakan dalam penilaian driver terbaik, selain itu juga dapat menentukan driver yang layak menerima bonus.

Hasil analisa yang dilakukan bagian HRD maka didapatkan penilaian berdasarkan perangkingan. Perangkingan tertinggi diperoleh oleh Anton Fatoni dengan nilai vektor sebesar 0.06436 dan berhak mendapatkan bonus dari Perusahaan.

\section{DAFTAR PUSTAKA}

[1] Turban dkk, Decision Support System and Intelligent System (Sistem Pendukung Keputusan dan Sistem Cerdas), Andi, Yogyakarta, 2011.

[2] Lestari, S. Penerapan Metode Weighted Product Model Untuk Seleksi Calon Karyawan. Jurnal Sistem Informasi, 5(1), 2014.

[3] Ningrum,. Metode Weighted product (WP). Andi: Yogyakarta, 2012.

[4] Moh. Nazir, 2014. Metodologi Penelitian, Ghalia Indonesia, Bogor

[5] Sambani, E.B., Agustin, Y.H., \& Marlina, R. Sistem Pendukung Keputusan Kenaikan Jabatan Karyawan Plaza Asia Dengan Menggunakan Metode Weighted Product. CSRID Journal, 8(2), 121-130, 2016.

[6] R.S. Pressman, Software Engineering : a practitioner's approach (Rekayasa Perangkat Lunak: Pendekatan seorang praktisi), McGraw-Hill, New York, 2010. 